\title{
Direct and Residual Effect of Sulphur Fertilization on Growth, Yield and Quality of Mustard in a Soybean - Mustard Cropping System
}

\author{
K. Lakshman ${ }^{1,2 *}$, A.K. Vyas ${ }^{1,3}$, B.G. Shivakumar ${ }^{1,4}$, D.S. Rana ${ }^{1}$, \\ J. Layek ${ }^{1,5}$ and S. Munda ${ }^{1,6}$ \\ ${ }^{1}$ Division of Agronomy, IARI, New Delhi, India -110012 \\ ${ }^{2}$ Jute research Station, Katihar-854105, Bihar Agricultural University, Sabour, India \\ ${ }^{3}$ ADG(HRM), ICAR, New Delhi-110012 \\ ${ }^{4}$ IGFRI, Regional Research Station, Dharwad-580005 \\ ${ }^{5}$ Division of Natural Resource Management, ICAR (NEH Region), India-793103 \\ ${ }^{6}$ Division of Crop Production, NRRI, Cuttack, India- 753006
}

\begin{tabular}{|c|c|}
\hline & A B S T R A C T \\
\hline & A field experiment was conducted at IARI, Agronomy research farm, New Delhi during \\
\hline Ke y words & $\begin{array}{l}\text { 2009-11 for two consecutive years to study the effect of sulphur nutrition on soybean- } \\
\text { mustard cropping system (SMCS). The field trial was planned in split plot design to }\end{array}$ \\
\hline $\begin{array}{l}\text { Direct effect, } \\
\text { Oil content. }\end{array}$ & evaluate the residual effect as main plot representing combination of sulphur levels $(0,15$, \\
\hline $\begin{array}{l}\text { Sulphur levels, } \\
\text { test weight, }\end{array}$ & $\begin{array}{l}30 \text { and } 45 \mathrm{~kg} / \mathrm{ha} \text { ) and timing of sulphur application (100\% at basal, } 100 \% \text { at flowering and } \\
\text { split application as } 50 \% \text { basal }+50 \% \text { at flowering) applied to preceding soybean crop and }\end{array}$ \\
\hline Residual effect, & direct effect of $S$ levels $(0,20$ and $40 \mathrm{~kg} / \mathrm{ha})$ applied as a basal to mustard crop as a sub-plot \\
\hline Yield attributes. & $\begin{array}{l}\text { treatments. Residual effect of sulphur nutrition treatments applied to preceding soybean } \\
\text { crop found non-significant on growth parameters, yield attributes and in quality parameters }\end{array}$ \\
\hline Article Info & like oil content and oil yield of mustard. Where as in direct effect of Sulphur levels $(0,20$ \\
\hline $\begin{array}{l}\text { Accepted: } \\
17 \text { April } 2017 \\
\text { Available Online: } \\
10 \text { May } 2017\end{array}$ & $\begin{array}{l}\text { attributes. The treatment with } 40 \mathrm{~kg} / \mathrm{ha} \text { has recorded significantly higher number of } \\
\text { siliquae/plant }(204.9) \text {, seeds/siliqua }(14.47) \text {, test weight }(5.73 \mathrm{~g}) \text {, oil content }(38.90 \%) \text { and } \\
\text { oil yield }(711.07 \mathrm{~kg} / \mathrm{ha}) \text { of mustard seed compared to control and } 20 \mathrm{~kg} / \mathrm{ha} \text { sulphur } \\
\text { application. This study has demonstrated the importance of sulphur nutrition management } \\
\text { for improving yield of oilseed based cropping system. }\end{array}$ \\
\hline
\end{tabular}

\section{Introduction}

India is the fifth largest oilseed economy in the world. Among the seven edible oilseeds cultivated in India, Rapeseed-mustard contributes 28.6 per cent in the total oilseeds production sharing 27.8per cent in the India's oilseed economy and ranks third after soybean and groundnut. India accounts for about 11.12 per cent $(6.8 \mathrm{mt})$ of global mustard seed production with an average productivity of $1115 \mathrm{~kg} / \mathrm{ha}$. During the last seven years, there has been a considerable increase in productivity from $730 \mathrm{~kg} / \mathrm{ha}$ in 2006-07 to $1262 \mathrm{~kg} / \mathrm{ha}$ in 2014-15 however, it is much below than the global average of $1970 \mathrm{~kg} / \mathrm{hectare}$ (DRMR, 2015). In 2014-15, India imported 14.5 million tonnes of edible oils valued $\$ 10.5$ billion, included nearly 0.4 million tonnes of imported rapeseed oil, 
which many processors and traders are blending with indigenous mustard oil (ref: http://thewire.in/28269/does-india-needtransgenic-mustard1/). With the country's own annual edible oil production stuck at below 7.5 million tonnes, of which mustard's share is roughly a quarter, the need to raise domestic crop yields and thus cut dependence on imports cannot be doubted.

In India, mustard is commonly cultivated during rabi season in most of the cropping systems viz, Rice-mustard, maize-mustard, pigeon pea-mustard are common ones. Yield and quality of mustard is greatly influenced by the preceding crops in a particular cropping system. Nutrient exhaustive crops like rice and maize grown in the preceding season often reduce the potentiality of the succeeding mustard while the leguminous crops have positive influence. In recent years with the increasing area under soybean cultivation, the possibility of growing soybean-mustard in a sequence in many areas has become an important alternative to prevailing Rice- wheat cropping system in Northern plain zone. Vyas et al., (2008) reported important soybean based cropping systems practiced in India include soybeanwheat, soybean-chickpea, soybean -potato, soybean-safflower, soybean-linseed and soybean- mustard. The soybean-mustard is important cropping sequence in the northern plain zone, it is having a tremendous potential for increasing the oilseed production in the country.

The production constraints of rapeseedmustard crop are diverse in nature. One of the major constraints is inadequate and imbalanced nutrient supply. With use of high analysis fertilizers lacking sulphur and intensive cropping systems has led to sulphur deficiency and this is reported from larger area and variety of crops. Sulphur has several important functions in plant and it is important part of every living cell. Sulphur is required for the formation of chlorophyll and for the activity of ATP-sulphurylase (the enzyme involved in sulphur metabolism). It is involved in several important physiological functions in mustard including oil synthesis and act as precursor for synthesis of sulphur containing amino acids, namely cysteine $(26 \% \mathrm{~S})$, cystine $(27 \% \mathrm{~S})$ and methionine $(21 \% \mathrm{~S})$. It is an important constituent of glucosinolates and is needed for chlorophyll formation (Holmes, 1980).

Among the oilseed crops, rapeseed-mustard has the highest requirement of sulphur (Tandon, 1986). Balanced use of fertilizers especially sulphur is very crucial for a good mustard harvest (Aravind et al., 2009). Application of sulphur increased the yield of mustard by 12 to 48 per cent under irrigated and by 17 to 24 per cent under rainfed conditions (Aulakh and Pasricha, 1988). In terms of agronomic efficiency, each kilogram of sulphur increases the yield of mustard by $7.7 \mathrm{~kg}$ (Katyal et al., 1997). A significant increase in yield was observed with increase in sulphur levels up to $40 \mathrm{~kg} \mathrm{~S} / \mathrm{ha}$ in mustard based cropping system. Keeping all these points in view, this experiment was undertaken to study the direct influence of sulphur levels $(0,20$ and $40 \mathrm{~kg} \mathrm{~S} / \mathrm{ha})$ on mustard vis-à-vis the residual effect of $S$ nutrition treatments (levels and timing) applied to preceding soybean crop.

\section{Materials and Methods}

A field experiment was conducted for two consecutive years (2009-11), during November to April at the agronomy Research farm of ICAR- Indian Agricultural Research Institute, New Delhi located at latitude of $28^{0}$ $40 " \mathrm{~N}$ and $77^{\circ} 12^{\prime \prime} \mathrm{E}$ longitude at an altitude of $228.61 \mathrm{~m}$ above mean sea level at a new site each year. The soil of experimental sites was sandy loam in texture with low in organic 
carbon (0.48\%) and available $\mathrm{N}$ (266.4 $\mathrm{kg} / \mathrm{ha})$, medium in available $\mathrm{P}(8.0 \mathrm{~kg} / \mathrm{ha})$ and $\mathrm{K}(153 \mathrm{~kg} / \mathrm{ha})$ and low in available $\mathrm{S}(9.5$ $\mathrm{ppm})$. The soil was slightly saline in nature ( $\mathrm{pH}$ 7.8). The experimental site has a semiarid and sub-tropical climate with hot dry summers and severe cold winters. The mean maximum and minimum daily temperatures were highest at the time of sowing of soybean in June -July (40 and $24^{\circ} \mathrm{C}$ ) and gradually decreased to 31 and $15^{\circ} \mathrm{C}$ respectively during harvest in September. The temperature drop to lowest values in January $\left(13.2\right.$ and $1.9^{\circ} \mathrm{C}$ ) during mustard growing season and gradually reach to 35 and $19^{\circ} \mathrm{C}$ in April. Mean (56 years) annual rain fall was recorded $769 \mathrm{~mm}$ (January-December), with nearly 85 per cent of this being received during July to September and the rest during October to May. Experiment is conducted in split plot design, with three replications and the treatment allocation to experimental plots is given in table 1 .

Land was prepared after harvesting of preceding soybean crop during October without disturbing plots. Mustard variety "Pusa Jai Kisan" was used as test crop and raised with a seed rate of $5 \mathrm{~kg} / \mathrm{ha}$. Crop was sown by placing the seeds in the furrow opened with manual drawn plough (kera method) in rows at $45 \mathrm{~cm}$ apart on $17^{\text {th }}$ and $8^{\text {th }}$ November of 2009 and 2010 and it was harvested on $26^{\text {th }}$ and $3^{\text {rd }}$ March in 2010 and 2011, respectively. Gap filling was done one week after germination, wherever necessary. Thinning was done 15 days after sowing (DAS) to maintain an intra plant spacing of 5 $\mathrm{cm}$ and crop is raised as per the recommended package of practices with 80 $\mathrm{kg} \mathrm{N}, 60 \mathrm{~kg} \mathrm{P}_{2} \mathrm{O}_{5}$ and $40 \mathrm{~kg} \mathrm{~K}_{2} \mathrm{O} /$ hectare. Four irrigations were given to mustard crop during both the years of experimentation. Weeds were managed through pre-emergence application of pendimethalin (1 $\mathrm{kg}$ a.i/ha in500 liters of water) and two manual weeding at 19 and 40 days after sowing was done. The crop was harvested at physiological maturity stage.

Chemical analysis of plant and soil samples were done using standard procedures (Prasad, 1998). The nutrient (N, P, K and S) concentration of economic produce and stalks of mustard were determined and uptake was measured as product of nutrient concentration and yield. The analysis of variance (ANOVA) was done in split-plot design for mustard, various soil and plant observations were recorded. The significance of treatment differences was tested by $F$ (Variance ratio) test. Critical difference (CD) at 5 per cent level of significance $(\mathrm{P}=0.05)$ was worked out for comparison and statistical interpretation of treatments as per Gomez and Gomez (1984).

\section{Results and Discussion}

\section{Growth parameters}

Number of branches per plant recorded at 60 and 90 DAS (Days after sowing) in all the treatments were at par with each other except control in the residual effect of sulphur nutrition imposed to preceding soybean. Split Application of $45 \mathrm{~kg} \mathrm{~S} / \mathrm{ha}(50 \%$ basal+50\% flowering) recorded highest number of branches as compared to treatments received with lower levels of sulphur (15 and $30 \mathrm{~kg} \mathrm{~S}$ /ha) as a split and sole (either at basal or at flowering) application of sulphur to the preceding soybean. Among the direct effect of sulphur levels $(0,20$ and $40 \mathrm{~kg} / \mathrm{ha})$ applied to mustard, treatment with $40 \mathrm{~kg}$ S/ha recorded significantly more number of branches per plant (7.05) over the treatments with 0 and 20 $\mathrm{kg} \mathrm{S} /$ ha level (Table 2). Direct application of sulphur to mustard increased the number of branches linearly with increased levels of $S$ application. This is in conformity with the finding of Chauhan et al., (1996). 
Dry matter accumulation and LAI (Leaf Area Index) of mustard was not significantly influenced by residual effect of sulphur treatments applied to preceding soybean crop whereas significant effect was found among the treatments received with direct application of sulphur in mustard crop. Among the treatments imposed to preceding soybean crop, application of $45 \mathrm{~kg} \mathrm{~S} / \mathrm{ha}$ in two splits (50\% basal and $50 \%$ at flowering) recorded highest LAI (0.69, 1.71 and 1.75) and dry matter accumulation (3.80, 33.04 and 85.29 $\mathrm{g} /$ plant) at 30, 60 and 90 DAS respectively.

Direct effect of $40 \mathrm{~kg} \mathrm{~S} / \mathrm{ha}$ application to the mustard recorded significantly higher LAI (0.69, 1.72 and 1.76) and dry matter accumulation $(3.85,33.26$ and 85.92 g/plant) of mustard at 30,60 and 90 DAS respectively, as compared to the treatments with $0 \mathrm{~kg} \mathrm{~S} / \mathrm{ha}$ and $20 \mathrm{~kg} \mathrm{~S} / \mathrm{ha}$. The LAI was also increased significantly and linearly with the increasing levels of sulphur indicating the higher sulphur demand of mustard. Khanpara et al., (1993) also reported that increasing level of sulphur increased LAI in mustard. The drymatter accumulation is more sensitive to nutrition of sulphur, indicating low efficiency of mustard in utilization of residual sulphur. The direct application of sulphur recorded increased accumulation of dry matter linearly, indicating the necessity of additional sulphur application along with residual effect of sulphur in field condition. Several researchers earlier also reported positive effect of sulphur on dry matter accumulation in mustard (Khanpara et al., 1993; Singh and Gangasaran, 1993).

\section{Physiological indices}

There was no significant residual effect of $S$ application on mean Crop Growth Rate (CGR) recorded between 30-60 DAS and 6090 DAS. However, split application of $45 \mathrm{~kg}$ S/ha as (50\% basal and $50 \%$ at flowering) recorded higher value over treatments received one time application of sulphur either at basal or flowering stage. Direct application of $\mathrm{S}$ to mustard @ $40 \mathrm{~kg} / \mathrm{ha}$ recorded highest mean CGR at different growth stages, except at 60-90 DAS (Table $3)$. Whereas, there was no significant residual effect of $\mathrm{S}$ treatments applied to preceding soybean crop in soybean-mustard cropping sequence on mean Relative Growth Rate (RGR) during all the growth stages of mustard. Small amount of residual sulphur present at soil may not be sufficient enough to promote plant growth. Similarly, the mean relative growth was not observed to be affected significantly by residual sulphur applied to preceding soybean. On the contrary, the increasing sulphur levels applied to mustard brought about significant increase in mean CGR in both the years except at 6090 DAS in first. Similar increase in CGR and RGR due to sulphur application has been reported by Saha and Mandal (2000). This may be attributed to positive influence of sulphur application on various growth parameters viz. Number of branches, dry matter accumulation and LAI, these all ultimately resulted in significantly higher crop growth rate. There was no significant interaction effect of sulphur treatments imposed on preceding soybean and sulphur treatments provided to mustard. This may be possibly due to greater demand for sulphur in mustard and insufficiency of residual sulphur after the harvest of soybean in soybeanmustard cropping system.

\section{Yield attributes}

The number of siliquae per plant, seeds per siliqua and test weight were not significantly affected by the sulphur nutrition applied to preceding soybean crop, whereas treatment with application of $45 \mathrm{~kg} \mathrm{~S} / \mathrm{ha}$ in two splits (50\% basal and $50 \%$ at flowering) to preceding soybean recorded highest number of siliquae per plant (203.5), seeds/siliqua 
(14.20) and test weight of 5.68g (Table 4) compared to other treatments. This might be due to the fact that the seed development is greatly influenced by the sulphur, as mustard is rich in oil and glucosinolates which are in turn greatly dependent on the sulphur nutrition for their formation. The sufficient residual sulphur might have helped in increased seed filling leading to higher seeds per siliqua and development of individual seeds enhancing the test weight. Among the sulphur treatments applied to mustard, application of $40 \mathrm{~kg}$ S/ha recorded significantly highest number of siliqua per plant (204.9), seeds per siliqua (14.47) and test weight $(5.73 \mathrm{~g})$ of mustard compared to treatment received with 0 and $20 \mathrm{~kg} \mathrm{~S} / \mathrm{ha}$. The direct application of sulphur in sufficient quantity and easy availability brought about significant increase in yield parameters viz. siliquae/plant, seeds/siliqua and test weight. Chauhan et al., (1996) was also reported increase in yield parameters due to sulphur application in mustard.

\section{Seed yield, stover yield and harvest index}

Application of $45 \mathrm{~kg} \mathrm{~S} / \mathrm{ha}$ in two splits $(50 \%$ at basal and $50 \%$ at flowering) to preceding soybean recorded significantly highest seed yield (1.80t/ha), stover yield (4.5 t/ha) and harvest index $(29.47 \%)$ of mustard (Table 4$)$. This might be attributed to higher residual effect of sulphur in that treatment and its positive influence on the growth parameters and yield parameter culminating in higher seed yield. Such residual effects of sulphur applied in preceding crop on succeeding had also reported by (Chandel et al., 2003 and Bharathi and Poongothai, 2008). The sole application of $45 \mathrm{~kg} \mathrm{~S} / \mathrm{ha}$ either at basal or at flowering also recorded higher values of yield parameters over the lower levels of sulphur application, indicating that higher dose of sulphur to preceding crops led to higher residual effect and subsequently improved performance of succeeding crops.
Among the sulphur levels applied to mustard, $0,20 \& 40 \mathrm{~kg} / \mathrm{ha}$. Application of $40 \mathrm{~kg} \mathrm{~S} / \mathrm{ha}$ to mustard recorded significantly higher seed yield, stover yield and harvest index over application of $20 \mathrm{~kg} \mathrm{~S} / \mathrm{ha}$ and control. The positive effect of sulphur nutrition on the yield levels of mustard have also been observed by Bhagat and Soni (2000) and Bharati and Prasad (2003). This could be attributed to combined effect of increased availability and higher response of mustard to sulphur nutrition. As all the growth parameters starting from plant height, number of branches per plant, drymatter accumulation, leaf area index etc and yield parameters viz. siliquae per plant, seeds per plant and test weight were significantly influenced by the higher levels of sulphur which culminated in the higher seed yield and stover yield and also better conversion of biological yield into economical yield by significantly higher harvest index.

\section{Oil content and its yield}

The oil content in seeds and its yield of mustard was significantly higher with split application of $45 \mathrm{~kg} \mathrm{~S} / \mathrm{ha}(50 \%$ basal and $50 \%$ at flowering) to preceding soybean. Followed by $30 \mathrm{~kg} \mathrm{~S} / \mathrm{ha}$ as a split $(50 \%$ basal and $50 \%$ at flowering) and $45 \mathrm{~kg} \mathrm{~S} / \mathrm{ha}$ at flowering to preceding soybean. In direct effect, Sulphur application@ @ $40 \mathrm{~kg} / \mathrm{ha}$ to mustard recorded significantly higher oil content and its yield (Table 4). The oil content in mustard was significantly influenced by both the residual effect of sulphur treatments to preceding soybean and direct application of sulphur to mustard. Sulphur plays a very important role in seed development in mustard as it is an important component of oil. The increased availability of sulphur both in the form of residual sulphur applied to preceding soybean or directly applied sulphur to mustard recorded significant increase in the oil content and its yield. 
The oil content in seeds and oil yield recorded highest with treatments received $45 \mathrm{~kg} \mathrm{~S} / \mathrm{ha}$ either as a split or sole application (basal or flowering) to preceding soybean as compared to treatments received with lower levels (15, $30 \mathrm{~kg} \mathrm{~S} / \mathrm{ha}$ ). This might be due to higher quantity of sulphur as residue, which helped in uptake of sulphur. Tripathi and Sharma (1993) and Biswas et al., (1995) earlier reported positive effect of sulphur on oil content and its yield in mustard under sandy loam soils of Delhi. The higher demand for sulphur was further evident from the fact that the response was linear up to $40 \mathrm{~kg} \mathrm{~S} / \mathrm{ha}$. As the oil yield is a combined effect of increased oil content and higher yield, the higher oil content and seed yield due to application of $45 \mathrm{~kg} \mathrm{~S} / \mathrm{ha}$ split as 50\% basal and 50\% at flowering to preceding soybean and direct application of $40 \mathrm{~kg} \mathrm{~S} / \mathrm{ha}$ to mustard recorded significantly higher oil yield. Correlation and regression between different parameters showed that there was a positive and significant correlation existed between yield attributes (siliqua/plant and seeds/siliqua), seed yield and oil yield of mustard (Fig. 1).
Uptake by mustard and available N, P, K, $\mathrm{S}$ status in soil after harvest

As the nutrient uptake is a function of increased nutrient content and biomass production. In residual effect of $S$ applied to preceding soybean, the uptake of $\mathrm{N}, \mathrm{P}, \mathrm{K}$ and $\mathrm{S}$ in seed and stover of mustard were higher in the treatment received with split application of $45 \mathrm{~kg} \mathrm{~S} / \mathrm{ha}(50 \%$ basal and 50\% at flowering) and in direct effect treatment received with $40 \mathrm{~kg}$ level of S/ha to mustard recorded highest values of total nutrient uptake of $\mathrm{N}(76.53), \mathrm{P}(21.66), \mathrm{K}$ (55.85)\& $\mathrm{S}(25.74) \mathrm{kg} / \mathrm{ha}$ (Table 5). Further as total uptake is a function of uptake in seed and stover. Wen et al., (2003) observed the residual effect of sulphur. This might be due to better growth parameters and yield parameters observed in this treatment. This led to increased absorption of all the plant nutrients and increased accumulation as compared to other treatments.

Table.1 Allocation of treatments to soybean and mustard

\begin{tabular}{|c|c|c|c|}
\hline \multicolumn{2}{|c|}{ To preceding soybean (main plot) } & \multicolumn{2}{|c|}{ To Mustard (sub plot) } \\
\hline T1 & Control(No sulphur) & S1 & Control(No sulphur) \\
\hline $\mathrm{T} 2$ & $15 \mathrm{~kg}$ S/ha basal & S2 & $20 \mathrm{~kg} \mathrm{~S} / \mathrm{ha}$ \\
\hline $\mathrm{T} 3$ & $30 \mathrm{~kg}$ S/ha basal & S3 & $40 \mathrm{~kg} \mathrm{~S} / \mathrm{ha}$ \\
\hline $\mathrm{T} 4$ & $45 \mathrm{~kg} \mathrm{~S} / \mathrm{ha}$ basal & & \\
\hline T5 & $15 \mathrm{~kg}$ S/ha flowering & & \\
\hline T6 & $30 \mathrm{~kg} \mathrm{~S} / \mathrm{ha}$ flowering & & \\
\hline $\mathrm{T} 7$ & $45 \mathrm{~kg}$ S/ha flowering & & \\
\hline $\mathrm{T} 8$ & $15 \mathrm{~kg} \mathrm{~S} / \mathrm{ha}(50 \%$ basal $+50 \%$ flowering) & & \\
\hline T9 & $30 \mathrm{~kg} \mathrm{~S} / \mathrm{ha}(50 \%$ basal $+50 \%$ flowering) & & \\
\hline $\mathrm{T} 10$ & $45 \mathrm{~kg} \mathrm{~S} / \mathrm{ha}(50 \%$ basal $+50 \%$ flowering) & & \\
\hline
\end{tabular}


Table.2 Number of branches, LAI and dry matter accumulation (g/plant) of mustard at various stages of crop growth as influenced by treatments (pooled data of two years)

\begin{tabular}{|c|c|c|c|c|c|c|c|c|c|}
\hline \multirow[t]{2}{*}{ Treatment } & \multicolumn{2}{|c|}{ Branches/plant } & \multicolumn{3}{|c|}{ LAI } & \multicolumn{4}{|c|}{ Dry matter accumulation (g/plant) } \\
\hline & $\begin{array}{l}\text { 60 } \\
\text { DAS }\end{array}$ & $\begin{array}{l}\text { 90 } \\
\text { DAS }\end{array}$ & $\begin{array}{l}\text { 30 } \\
\text { DAS }\end{array}$ & $\begin{array}{l}\text { 60 } \\
\text { DAS }\end{array}$ & 90DAS & 30 DAS & $\begin{array}{l}\text { 60 } \\
\text { DAS }\end{array}$ & $\begin{array}{l}90 \\
\text { DAS }\end{array}$ & At harvest \\
\hline \multicolumn{10}{|c|}{$\begin{array}{l}\text { Levels and time of S application to preceding soybean } \\
(\mathrm{kg} / \mathrm{ha})\end{array}$} \\
\hline Control (no sulphur) & 6.07 & 9.35 & 0.60 & 1.65 & 1.68 & 3.36 & 30.22 & 79.97 & 93.68 \\
\hline $15 \mathrm{~kg}$ as basal & 6.35 & 9.97 & 0.64 & 1.67 & 1.71 & 3.54 & 31.02 & 81.58 & 96.44 \\
\hline $30 \mathrm{~kg}$ as basal & 6.66 & 10.32 & 0.65 & 1.68 & 1.73 & 3.70 & 31.75 & 83.87 & 97.80 \\
\hline $45 \mathrm{~kg}$ as basal & 6.84 & 10.50 & 0.67 & 1.70 & 1.73 & 3.80 & 32.57 & 84.82 & 100.29 \\
\hline $15 \mathrm{~kg}$ at flowering & 6.56 & 10.23 & 0.63 & 1.67 & 1.70 & 3.51 & 31.06 & 82.64 & 97.55 \\
\hline $30 \mathrm{~kg}$ at flowering & 6.68 & 10.43 & 0.66 & 1.68 & 1.72 & 3.64 & 31.45 & 83.12 & 97.81 \\
\hline $45 \mathrm{~kg}$ at flowering & 6.77 & 10.51 & 0.67 & 1.69 & 1.74 & 3.74 & 32.62 & 84.66 & 99.80 \\
\hline $\begin{array}{l}15 \mathrm{~kg} \text { as split ( } 50 \% \text { basal }+50 \% \text { at } \\
\text { flowering) }\end{array}$ & 6.61 & 10.06 & 0.65 & 1.68 & 1.71 & 3.63 & 31.43 & 83.29 & 98.18 \\
\hline $\begin{array}{l}30 \mathrm{~kg} \text { as split }(50 \% \text { basal }+50 \% \text { at } \\
\text { flowering) }\end{array}$ & 6.77 & 10.25 & 0.68 & 1.70 & 1.73 & 3.67 & 32.56 & 84.12 & 98.49 \\
\hline $\begin{array}{l}45 \mathrm{~kg} \text { as split ( } 50 \% \text { basal }+50 \% \text { at } \\
\text { flowering) }\end{array}$ & 6.91 & 10.51 & 0.69 & 1.71 & 1.75 & 3.80 & 33.04 & 85.29 & 100.86 \\
\hline $\mathrm{SEm} \pm$ & 0.179 & 0.234 & 0.010 & 0.015 & 0.012 & 0.082 & 0.394 & 0.694 & 0.72 \\
\hline $\operatorname{LSD}(\mathrm{P}=0.05)$ & 0.51 & 0.67 & 0.03 & 0.04 & 0.04 & 0.24 & 1.13 & 1.99 & 2.07 \\
\hline \multicolumn{10}{|c|}{ Levels of S applied to mustard as basal ( $\mathrm{kg} / \mathrm{ha})$} \\
\hline Control & 6.16 & 9.63 & 0.61 & 1.65 & 1.69 & 3.40 & 30.37 & 81.03 & 94.61 \\
\hline $20 \mathrm{~kg}$ & 6.66 & 10.13 & 0.66 & 1.69 & 1.71 & 3.67 & 31.69 & 83.06 & 98.10 \\
\hline $40 \mathrm{~kg}$ & 7.05 & 10.88 & 0.69 & 1.72 & 1.76 & 3.85 & 33.26 & 85.92 & 101.56 \\
\hline $\mathrm{SEm} \pm$ & 0.096 & 0.141 & 0.003 & 0.004 & 0.005 & 0.050 & 0.202 & 0.298 & 0.35 \\
\hline $\operatorname{LSD}(\mathrm{P}=0.05)$ & 0.27 & 0.40 & 0.01 & 0.01 & 0.01 & 0.14 & 0.57 & 0.84 & 0.99 \\
\hline
\end{tabular}


Table.3 Physiological indices of mustard at various stages of crop growth as influenced by treatments (pooled data of two years)

\begin{tabular}{|c|c|c|c|c|c|c|}
\hline \multirow[t]{2}{*}{ Treatment } & \multicolumn{3}{|c|}{ Mean CGR(g/day/cm²) } & \multicolumn{3}{|c|}{ Mean RGR(g/g/day) } \\
\hline & $\begin{array}{l}30-60 \\
\text { DAS }\end{array}$ & $\begin{array}{l}\text { 60-90 } \\
\text { DAS }\end{array}$ & $\begin{array}{l}\text { 90-At } \\
\text { harvest }\end{array}$ & $\begin{array}{l}30-60 \\
\text { DAS }\end{array}$ & \begin{tabular}{|l|}
60 -90 \\
DAS \\
\end{tabular} & $\begin{array}{l}\text { 90-At } \\
\text { harvest }\end{array}$ \\
\hline \multicolumn{7}{|c|}{ A. Residual effect of sulphur treatments applied to previous crop } \\
\hline Control & 0.90 & 1.66 & 0.34 & 0.0734 & 0.0324 & 0.0052 \\
\hline $15 \mathrm{~kg} \mathrm{~S} / \mathrm{ha}$ as basal & 0.92 & 1.69 & 0.37 & 0.0725 & 0.0322 & 0.0056 \\
\hline $30 \mathrm{~kg} \mathrm{~S} / \mathrm{ha}$ as basal & 0.94 & 1.74 & 0.35 & 0.0718 & 0.0324 & 0.0051 \\
\hline $45 \mathrm{~kg} \mathrm{~S} / \mathrm{ha}$ as basal & 0.96 & 1.74 & 0.39 & 0.0716 & 0.0319 & 0.0056 \\
\hline $15 \mathrm{~kg} \mathrm{~S} / \mathrm{ha}$ at flowering & 0.92 & 1.72 & 0.37 & 0.0729 & 0.0326 & 0.0055 \\
\hline $30 \mathrm{~kg} \mathrm{~S} / \mathrm{ha}$ at flowering & 0.93 & 1.72 & 0.37 & 0.0722 & 0.0324 & 0.0054 \\
\hline $45 \mathrm{~kg} \mathrm{~S} / \mathrm{ha}$ at flowering & 0.96 & 1.73 & 0.38 & 0.0723 & 0.0319 & 0.0055 \\
\hline $15 \mathrm{~kg} \mathrm{~S} / \mathrm{ha}$ as $50 \%$ basal $+50 \%$ at flowering & 0.93 & 1.73 & 0.37 & 0.0722 & 0.0325 & 0.0055 \\
\hline $30 \mathrm{~kg}$ S $/ \mathrm{ha}$ as $50 \%$ basal $+50 \%$ at flowering & 0.96 & 1.72 & 0.36 & 0.0729 & 0.0317 & 0.0052 \\
\hline $45 \mathrm{~kg}$ S/ha as $50 \%$ basal $+50 \%$ at flowering & 0.97 & 1.74 & 0.39 & 0.0723 & 0.0317 & 0.0056 \\
\hline $\mathrm{SEm} \pm$ & 0.014 & 0.028 & 0.020 & 0.0009 & 0.0005 & 0.0003 \\
\hline $\operatorname{LSD}(\mathrm{P}=0.05)$ & 0.04 & 0.08 & 0.06 & 0.0025 & 0.0015 & 0.0009 \\
\hline \multicolumn{7}{|l|}{ Levels of $\mathrm{S}$ applied to mustard as basal $(\mathrm{kg} / \mathrm{ha})$} \\
\hline Control & 0.90 & 1.69 & 0.34 & 0.0733 & 0.0327 & 0.0051 \\
\hline $20 \mathrm{~kg} \mathrm{~S} / \mathrm{ha}$ & 0.93 & 1.71 & 0.38 & 0.0720 & 0.0321 & 0.0055 \\
\hline $40 \mathrm{~kg} \mathrm{~S} / \mathrm{ha}$ & 0.98 & 1.76 & 0.39 & 0.0719 & 0.0317 & 0.0056 \\
\hline SEm \pm & 0.007 & 0.012 & 0.009 & 0.0005 & 0.0002 & 0.0001 \\
\hline $\operatorname{LSD}(\mathrm{P}=0.05)$ & 0.02 & 0.03 & 0.03 & 0.0013 & 0.0007 & 0.0004 \\
\hline
\end{tabular}


Table.4 Yield attributes, Seed yield, stover yield, harvest index, oil \% and oil yield of mustard as influenced by treatments (pooled data of two years)

\begin{tabular}{|c|c|c|c|c|c|c|c|c|}
\hline \multirow[t]{2}{*}{ Treatment } & \multicolumn{3}{|c|}{ Yield attributes } & \multirow{2}{*}{$\begin{array}{l}\text { Seed } \\
\text { yield } \\
\text { (t/ha) }\end{array}$} & \multirow{2}{*}{$\begin{array}{l}\text { Stover yield } \\
\text { (t/ha) }\end{array}$} & \multirow{2}{*}{$\begin{array}{c}\text { Harvest } \\
\text { index } \\
(\%)\end{array}$} & \multirow{2}{*}{$\begin{array}{l}\text { Oil } \\
(\%)\end{array}$} & \multirow{2}{*}{$\begin{array}{c}\text { Oil } \\
\text { yield } \\
\text { (kg/ha) }\end{array}$} \\
\hline & $\begin{array}{l}\text { No of } \\
\text { pods/plant }\end{array}$ & $\begin{array}{l}\text { No } \\
\text { seeds/siliqua }\end{array}$ & $\begin{array}{l}\text { Test } \\
\text { wt } \\
(\mathrm{g})\end{array}$ & & & & & \\
\hline \multicolumn{9}{|c|}{ Levels and time of application of S to preceding soybean $(\mathrm{kg} / \mathrm{ha})$} \\
\hline Control & 195.3 & 12.97 & 5.26 & 1.58 & 4.29 & 27.15 & 36.94 & 584.31 \\
\hline $15 \mathrm{~kg} \mathrm{~S} / \mathrm{ha}$ as basal & 198.6 & 13.33 & 5.35 & 1.66 & 4.43 & 27.84 & 37.78 & 626.48 \\
\hline $30 \mathrm{~kg} \mathrm{~S} / \mathrm{ha}$ as basal & 200.0 & 13.76 & 5.47 & 1.70 & 4.44 & 28.21 & 37.89 & 643.34 \\
\hline $45 \mathrm{~kg} \mathrm{~S} / \mathrm{ha}$ as basal & 202.2 & 13.77 & 5.63 & 1.77 & 4.50 & 29.12 & 38.50 & 684.00 \\
\hline $15 \mathrm{~kg} \mathrm{~S} / \mathrm{ha}$ at flowering & 198.5 & 13.74 & 5.38 & 1.63 & 4.43 & 27.65 & 38.00 & 620.98 \\
\hline $30 \mathrm{~kg} \mathrm{~S} / \mathrm{ha}$ at flowering & 201.4 & 13.94 & 5.53 & 1.70 & 4.45 & 28.65 & 38.33 & 653.43 \\
\hline $45 \mathrm{~kg} \mathrm{~S} / \mathrm{ha}$ at flowering & 203.5 & 14.06 & 5.64 & 1.78 & 4.48 & 29.40 & 38.54 & 684.80 \\
\hline $15 \mathrm{~kg} \mathrm{~S} / \mathrm{ha}$ as $50 \%$ basal $+50 \%$ at flowering & 199.5 & 13.52 & 5.60 & 1.68 & 4.42 & 28.17 & 38.35 & 642.66 \\
\hline $30 \mathrm{~kg} \mathrm{~S} / \mathrm{ha}$ as $50 \%$ basal $+50 \%$ at flowering & 201.8 & 14.00 & 5.66 & 1.77 & 4.47 & 29.29 & 38.73 & 687.52 \\
\hline $45 \mathrm{~kg} \mathrm{~S} / \mathrm{ha}$ as $50 \%$ basal $+50 \%$ at flowering & 203.5 & 14.20 & 5.68 & 1.80 & 4.50 & 29.47 & 39.19 & 706.73 \\
\hline $\mathrm{SEm}+$ & 2.14 & 0.14 & 0.05 & 0.017 & 0.047 & 0.353 & 0.088 & 6.283 \\
\hline $\operatorname{LSD}(\mathrm{P}=0.05)$ & 6.13 & 0.39 & 0.15 & 0.05 & 0.14 & 1.01 & 0.25 & 18.02 \\
\hline \multicolumn{9}{|c|}{ Levels of S applied as a basal to mustard $(\mathrm{kg} / \mathrm{ha})$} \\
\hline Control & 196.5 & 13.14 & 5.28 & 1.59 & 4.34 & 27.44 & 37.60 & 599.06 \\
\hline $20 \mathrm{~kg} \mathrm{~S} / \mathrm{ha}$ & 200.0 & 13.57 & 5.55 & 1.70 & 4.43 & 28.45 & 38.18 & 650.15 \\
\hline $40 \mathrm{~kg} \mathrm{~S} / \mathrm{ha}$ & 204.9 & 14.47 & 5.73 & 1.83 & 4.55 & 29.59 & 38.90 & 711.07 \\
\hline $\mathrm{SEm}+$ & 0.78 & 0.02 & 0.02 & 0.005 & 0.011 & 0.081 & 0.040 & 1.908 \\
\hline $\operatorname{LSD}(\mathrm{P}=0.05)$ & 2.20 & 0.05 & 0.07 & 0.01 & 0.03 & 0.23 & 0.11 & 5.37 \\
\hline
\end{tabular}


Table.5 Total uptake by mustard and available status of nitrogen, phosphorus, potassium and sulphur after harvest as influenced by treatments (pooled data of two years)

\begin{tabular}{|c|c|c|c|c|c|c|c|c|}
\hline \multirow[b]{2}{*}{ Treatment } & \multicolumn{4}{|c|}{ Total uptake } & \multicolumn{4}{|c|}{ Available nutrient status } \\
\hline & $\begin{array}{c}\mathrm{N} \\
\text { (kg/ha) }\end{array}$ & $\begin{array}{c}\mathbf{P} \\
(\mathrm{kg} / \mathrm{ha})\end{array}$ & $\begin{array}{c}\text { K } \\
\text { (kg/ha) }\end{array}$ & $\begin{array}{c}\text { S } \\
\text { (kg/ha) }\end{array}$ & $\mathbf{N}$ (kg/ha) & $\begin{array}{c}\mathbf{P} \\
\text { (kg/ha) }\end{array}$ & $\begin{array}{c}\text { K } \\
\text { (kg/ha) }\end{array}$ & $\begin{array}{c}\text { S } \\
\text { (kg/ha ) }\end{array}$ \\
\hline \multicolumn{9}{|c|}{ Levels and time of application of S to preceding soybean $(\mathrm{kg} / \mathrm{ha})$} \\
\hline Control & 63.73 & 17.28 & 50.46 & 20.82 & 206.16 & 14.66 & 165.88 & 8.67 \\
\hline $15 \mathrm{~kg} \mathrm{~S} / \mathrm{ha}$ as basal & 66.23 & 18.43 & 51.85 & 21.86 & 197.78 & 13.90 & 160.96 & 9.67 \\
\hline $30 \mathrm{~kg} \mathrm{~S} / \mathrm{ha}$ as basal & 68.24 & 19.22 & 52.99 & 23.14 & 191.77 & 12.79 & 156.05 & 9.80 \\
\hline $45 \mathrm{~kg} \mathrm{~S} / \mathrm{ha}$ as basal & 71.36 & 20.66 & 54.71 & 24.43 & 184.90 & 13.42 & 150.12 & 9.89 \\
\hline $15 \mathrm{~kg} \mathrm{~S} / \mathrm{ha}$ at flowering & 67.85 & 18.36 & 52.63 & 22.97 & 197.27 & 14.37 & 158.59 & 9.62 \\
\hline $30 \mathrm{~kg} \mathrm{~S} / \mathrm{ha}$ at flowering & 71.77 & 20.08 & 53.71 & 24.75 & 196.64 & 13.56 & 151.17 & 9.89 \\
\hline $45 \mathrm{~kg}$ S/ha at flowering & 72.62 & 20.85 & 54.56 & 24.93 & 191.33 & 12.55 & 145.40 & 10.21 \\
\hline $15 \mathrm{~kg}$ S/ha as $50 \%$ basal+ $50 \%$ at flowering & 70.87 & 19.40 & 53.41 & 23.73 & 193.49 & 13.68 & 148.97 & 9.95 \\
\hline $30 \mathrm{~kg} \mathrm{~S} / \mathrm{ha}$ as $50 \%$ basal+ $50 \%$ at flowering & 73.93 & 20.84 & 54.38 & 24.66 & 190.76 & 12.64 & 141.86 & 10.12 \\
\hline $45 \mathrm{~kg} \mathrm{~S} / \mathrm{ha}$ as $50 \%$ basal $+50 \%$ at flowering & 76.32 & 21.92 & 55.91 & 26.23 & 186.35 & 12.09 & 139.12 & 10.18 \\
\hline SEm \pm & 0.634 & 0.359 & 0.719 & 0.365 & 1.547 & 0.786 & 2.101 & 0.032 \\
\hline $\operatorname{LSD}(\mathrm{P}=0.05)$ & 1.82 & 1.03 & 2.06 & 1.05 & 4.44 & NS & 6.02 & 0.09 \\
\hline \multicolumn{9}{|l|}{ Levels of S applied as a basal to mustard ( $\mathrm{kg} / \mathrm{ha})$} \\
\hline Control & 63.96 & 17.68 & 51.00 & 21.73 & 201.33 & 15.29 & 160.13 & 9.50 \\
\hline $20 \mathrm{~kg} \mathrm{~S} / \mathrm{ha}$ & 70.49 & 19.77 & 53.53 & 23.79 & 193.10 & 13.11 & 151.17 & 9.79 \\
\hline $40 \mathrm{~kg} \mathrm{~S} / \mathrm{ha}$ & 76.43 & 21.66 & 55.85 & 25.74 & 186.51 & 11.70 & 144.13 & 10.11 \\
\hline SEm \pm & 0.182 & 0.080 & 0.113 & 0.091 & 0.100 & 0.116 & 0.161 & 0.010 \\
\hline $\operatorname{LSD}(\mathrm{P}=0.05)$ & 0.51 & 0.22 & 0.32 & 0.26 & 0.28 & 0.33 & 0.45 & 0.03 \\
\hline
\end{tabular}


Fig.1 Relation between yield attributes with seed and oil yield
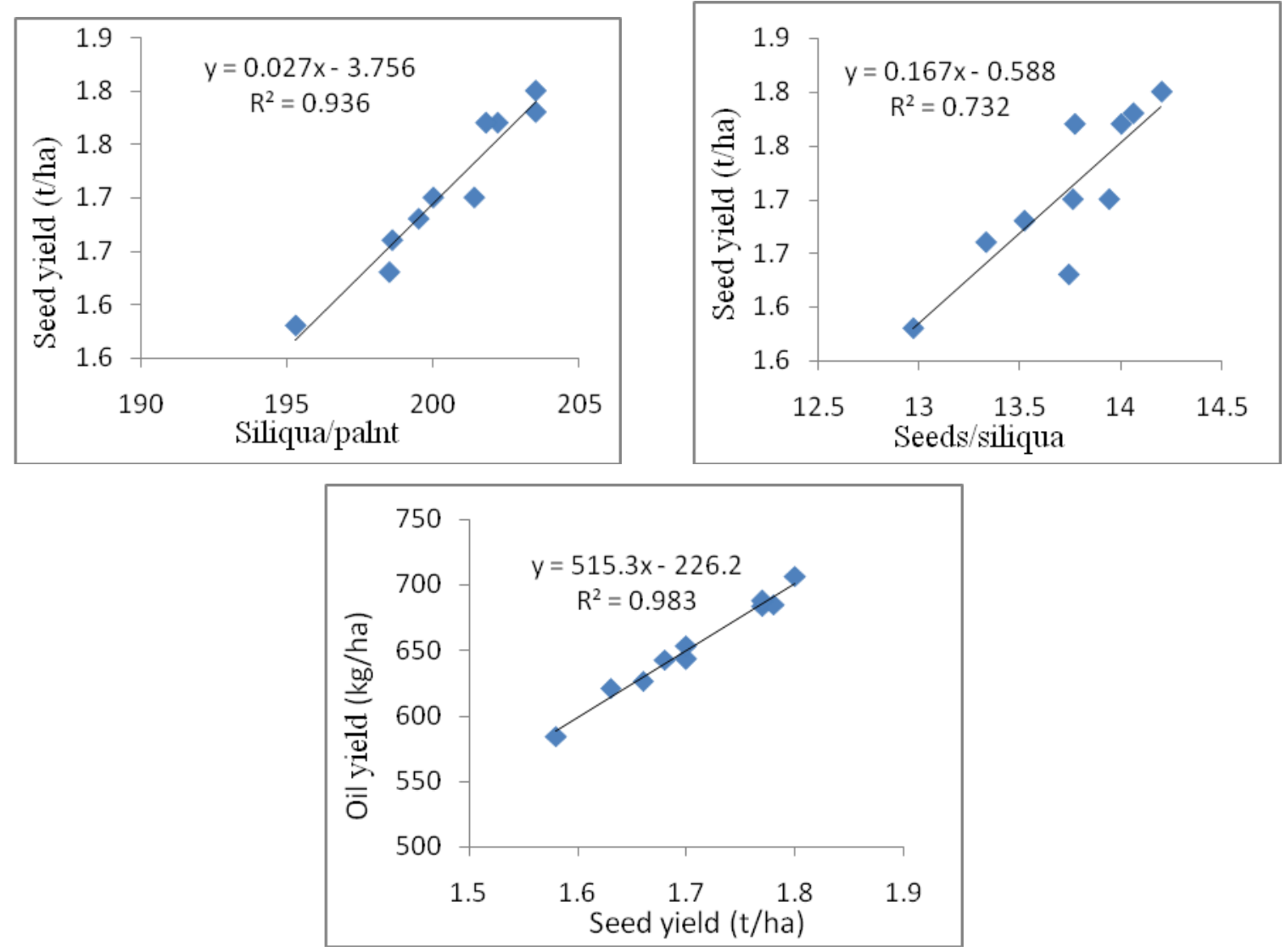

Further the direct application of sulphur to mustard, recorded highest $\mathrm{N}, \mathrm{P}, \mathrm{K}$ and $\mathrm{S}$ contents in seed and stover. This might be attributed to overall improved growth leading to higher absorption of nutrients due to complementary effect of sulphur on other nutrients like $\mathrm{N}, \mathrm{P}$ and $\mathrm{K}$. The increased availability of sulphur due to these treatments led to increased accumulation.

In residual effect the highest available nutrient status(kg/ha) of $\mathrm{N}(206.16), \mathrm{P}(14.66)$ and $\mathrm{K}(165.88)$ in the soil after the harvest of mustard was recorded with no sulphur application to preceding soybean where as highest available $\mathrm{S}(25.74)$ in soil was recorded in treatment received with application of $45 \mathrm{~kg} \mathrm{~S} / \mathrm{ha}$ as a split (50\% basal and $50 \%$ flowering) to preceding soybean (Table 5). The lowest available N, P, K. status in soil was recorded with application of $45 \mathrm{~kg}$ S/ha split as $50 \%$ basal and $50 \%$ at flowering to preceding soybean and lowest available $S$ was observed with no application of $S$ to preceding soybean. In direct effect of sulphur levels applied to mustard, the application of no sulphur to mustard recorded higher available $\mathrm{N}, \mathrm{P}$ and $\mathrm{K}$ status after the harvest of mustard, while the highest available $\mathrm{S}$ was recorded with application of $40 \mathrm{~kg} \mathrm{~S} / \mathrm{ha}$. Conversely, the lowest available N, P and K in soil was with application of $40 \mathrm{~kg} \mathrm{~S} / \mathrm{ha}$ and lowest available $\mathrm{S}$ was with no application of sulphur to mustard in both the years of experimentation.

In conclusion, based on 2 years study, It is concluded that the residual effect of sulphur nutrition treatments on yield attributes, yield and quality of mustard were only seen in 
treatments received with application of sulphur in two splits at $(50 \%$ basal and $50 \%$ flowering) compared to treatments received with sole application of sulphur either as a basal or at flowering only. Direct effect of sulphur application to mustard crop was found to be more effective than the residual effect of sulphur applied to previous soybean crop in soybean-mustard cropping sequence. Among the three levels of sulphur (0,20 and $40 \mathrm{~kg} \mathrm{~S} / \mathrm{ha}$ ) applied to mustard, the treatment with $40 \mathrm{~kg}$ sulphur level of application to mustard recorded higher growth and yield of mustard, showing in mustard crop the response to applied sulphur is up to level of $40 \mathrm{~kg} / \mathrm{ha}$ application.

\section{References}

Aravind Kumar, Pankaj Sharma, Lijo Thomas, Abha Agnihotri and Banga, S.S. 2009. Canola cultivation in India: scenario and future strategy. $16^{\text {th }}$ Australian Research Assembly on Brassicas, Ballarat Victoria, Australia.

Aulakh, M.S. and Pasricha, N.S. 1988. Sulphur fertilization of oilseeds for yield and quality. TSI-FAI symposium, Sulphur in Indian Agriculture-S-11/3.

Bhagat, K.L. and Soni, K.C. 2000. Effect of nitrogen and sulphur on growth, seed and oil yield of mustard (Brassica juncea). J. Oilseeds Res., 17(1): 96-99.

Bharathi, C. and Poongothai, S. 2008. Direct and residual effect of Sulphur on growth, nutrient uptake, yield and its use efficiency in Maize and subsequent Green gram. Res. J. Agri. Biol. Sci., 4(5): 368-372.

Biswas, D.R., Ali, S.A. and Khera, M.S. 1995. Response of Ghobi Sarson (Brassica napus L. ASN-706) to nitrogen and sulphur. J. Indian Soc. Soil Sci., 43: 220.

Chandel, R.S., Singh Kalyan, Singh, A.K. and Sudhakar, P.C. 2003. Effect of sulphur nutrition in rice (Oryza sativa L.) and mustard (Brassica juncea L. Czern and Coss.) grown in sequence. Indian $J$. Plant Physiol., 8(2):155-159.

Chauhan, D.R., Paroda, S. and Ram, M. 1996. Response of Indian mustard to biofertilizers, sulphur and nitrogen fertilization. Indian J. Agron., 41(4): 600-603.

DRMR. 2015. Annual Progress Report of All India Coordinated Research Project on Rapeseed-Mustard pp. A1-22.

Gangasaran and Giri, G. 1986. Growth and yield of mustard as influenced by irrigation and plant population. Annals of Agri. Res., 7(1): 68-74.

Gomez, K.A. and Gomez, A.A. 1984. Statistical Procedures for Agricultural Research. 2nd Edition, John Wiley and Sons, New York.

Katyal, J.C., Sharma, K.L. and Srinivas, K. 1997. $\mathrm{S}$ in Indian Agriculture, pp.KS2/1-2/12.

Khanpara, V.D., Porwal, B.L., Sahu, M.P. and Patel, J.C. 1993. Effect of nitrogen and sulphur on growth and yield of mustard (Brassica. juncea). Indian J. Agron., 38(2): 266-269.

Saha, A. and Mandal, B.K. 2000. Growth and yield of yellow sarson and mustard in relation to sulphur nitrogen in lowland entisol under rainfed condition. J. Oilseeds Res., 17(2): 307-314.

Sharma, R.S., Agrawal, K.K. and Jain, K.K. 1994. Influence of spatial arrangement and nitrogen levels on light utilization and productivity in maize-soybean intercropping system. J. Oilseeds Res., 11(2): 217-221.

Shekhawat, K., Rathore, S.S., Premi, O.P., Kandpal, B.K. and Chauhan, J.S. 2012. Advances in Agronomic Management of Indian Mustard (Brassica juncea (L.) Czernj. Cosson): An Overview. Int. J. Agron., 1-14.

Tandon, H.L.S. 1986. Sulphur Research and Agricultural Production in India. 
Second Edition. Fertilizer Development and Consultation Organization, New Delhi, pp-160.

Tripathi, P.N. and Sharma, N.L. 1995. Effect of gypsum and pyrites on yield and quality of mustard in salt affected soils of Western U.P. J. Indian Soc. Soil Sci., 43(2): 290-291.

Vision 2050.DRMR. 2015. Directorate of Rap eseed and Mustard, Sewar, Bharatpur, R ajasthan.

http://www.drmr.res.in/aboutrm.html

Vyas, A.K., Billore, S.D., Chauhan, G.S. and Pandya, N. 2008. Agro-economic analysis of soybean -based cropping systems. Indian J. Fertilizers, 4(5): 4154.

\section{How to cite this article:}

Lakshman, K., A.K. Vyas, B.G. Shivakumar, D.S. Rana, J. Layek and Munda, S. 2017. Direct and Residual Effect of Sulphur Fertilization on Growth, Yield and Quality of Mustard in a Soybean - Mustard Cropping System. Int.J.Curr.Microbiol.App.Sci. 6(5): 1500-1512. doi: https://doi.org/10.20546/ijcmas.2017.605.163 